\title{
Use of 16S rRNA Analysis To Investigate Phylogeny of Methylotrophic Bacteria
}

\author{
BONNIE JO BRATINA, $†$ GREGORY A. BRUSSEAU, AND RICHARD S. HANSON* \\ Gray Freshwater Biological Institute, Department of Microbiology, \\ University of Minnesota, Navarre, Minnesota 55392
}

\begin{abstract}
Small-subunit rRNAs from 24 gram-negative methylotrophic bacteria have been sequenced. A phylogenetic tree was constructed on the basis of sequence similarities by using a weighted least-mean-square difference method. The methylotrophs were separated into coherent clusters in which bacteria in each group shared physiological characteristics.
\end{abstract}

Methylotrophic bacteria are a diverse group of microbes that utilize one-carbon compounds more reduced than carbon dioxide as sole energy sources. In addition, these organisms assimilate carbon from the primary substrate at the oxidation level of formaldehyde for the synthesis of cell material $(2,25)$. Bacteria able to grow on methane are a subset of methylotrophs called methanotrophs. One of the criteria for the traditional classification of methanotrophs is the pathway used for formaldehyde assimilation $(2,8,22)$. The two dissimilar pathways used by methylotrophic bacteria are the ribulose monophosphate (RuMP) and serine pathways. Methanotrophs are further differentiated on the basis of arrangement of intracytoplasmic membranes, predominance of specific membrane phospholipid fatty acids, and other properties into groups I, II, and $X(5,7,21)$. Methanotrophs also possess a utilitarian mixed-function oxidase, methane monooxygenase (MMO), that effects the conversion of methane to methanol. This enzyme has a broad substrate specificity and catalyzes the oxidation of a wide variety of aliphatic, alicyclic, and aromatic hydrocarbons (21). There are two forms of MMO-soluble and membrane bound (also known as particulate MMO) (14). The soluble MMO is able to oxidize a wider range of compounds than the particulate enzyme $(3,4)$ and has been observed to be expressed only in group II methanotrophs of the genus "Methylosinus" and in one group X methanotroph $(3,19)$.

Methylotrophs may play an important role in two current environmental concerns-global warming and groundwater contamination. Methane is an abundant organic gas in the atmosphere, and its concentration has been increasing at the alarming rate of $1 \%$ per year for the last 150 to 200 years (16). This gas absorbs infrared radiation more efficiently than carbon dioxide and may contribute more than carbon dioxide to global warming in the next century. Understanding the role of methanotrophs in the global carbon cycle is imperative. Recent research has demonstrated that soluble MMO oxidizes several groundwater pollutants, including trichloroethylene, vinyl chloride, and other halogenated hydrocarbons $(10,18)$. Other methylotrophs have been demonstrated to metabolize the common industrial solvent dichloromethane (12). With such diverse organisms and potentially im-

TABLE 1. Descriptions and sources of methylotrophs sequenced

\begin{tabular}{llcc}
\hline \multicolumn{1}{c}{ Organism } & $\begin{array}{c}\text { Carbon source } \\
\text { for growth }\end{array}$ & $\begin{array}{c}\text { Pathway for formal- } \\
\text { dehyde assimilation }\end{array}$ & Source $^{a}$ \\
\hline Methylomonas sp. strain A4 & Methane & RuMP & M. Lidstrom \\
"Methylomonas alba" BG8 & Methane & RuMP & R. Whittenbury \\
Methylomonas lutea & Methane & RuMP & NCIMB 11914 \\
"Methylomonas rubra" & Methane & RuMP & NCIMB 11913 \\
"Methylobacillus flagellatus KT1 & Methanol & RuMP & Y. Trotsenko \\
Methylobacillus glycogenes & Methanol & RuMP & ATCC 29475 \\
Methylomonas methanolica & Methanol & RuMP & ATCC 21852 \\
Methylomonas methylovora & Methanol & RuMP & ATCC 21852 \\
"Methylosinus" sp. strain B & Methane & Serine & This laboratory \\
"Methylosinus" sp. strain LAC & Methane & Serine & This laboratory \\
"Methylosinus sporium" & Methane & Serine & Y. Trotsenko \\
Methylobacterium sp. strain M27 & Methanol & Serine & NCIMB 9686 \\
Methylobacterium extorquens & Methanol & Serine & 1 \\
Strain PK-1 & Methanol & Serine & 22 \\
Strain PR-6 & Methanol & Serine & S. Hirano \\
\hline
\end{tabular}

${ }^{a}$ Strains were obtained directly from the indicated culture collection or individuals. ATCC, American Type Culture Collection, Rockville, Md.; NCIMB, National Collections of Industrial and Marine Bacteria, Aberdeen, Scotland; S. Hirano, University of Wisconsin, Madison; M. Lidstrom, California Institute of Technology, Pasadena; Y. Trotsenko, Russian Academy of Sciences, Puschino, Moscow Region; R. Whittenbury, University of Warwick, Coventry, England.

$b$ This strain was originally designated Methylococcus luteus NCIMB 11914. The name was changed here to reflect the findings of previous work (11) and data included in this paper.

\footnotetext{
* Corresponding author.

$\dagger$ Present address: Department of Microbiology, Miami University, Oxford, $\mathrm{OH} 45056$.
} 


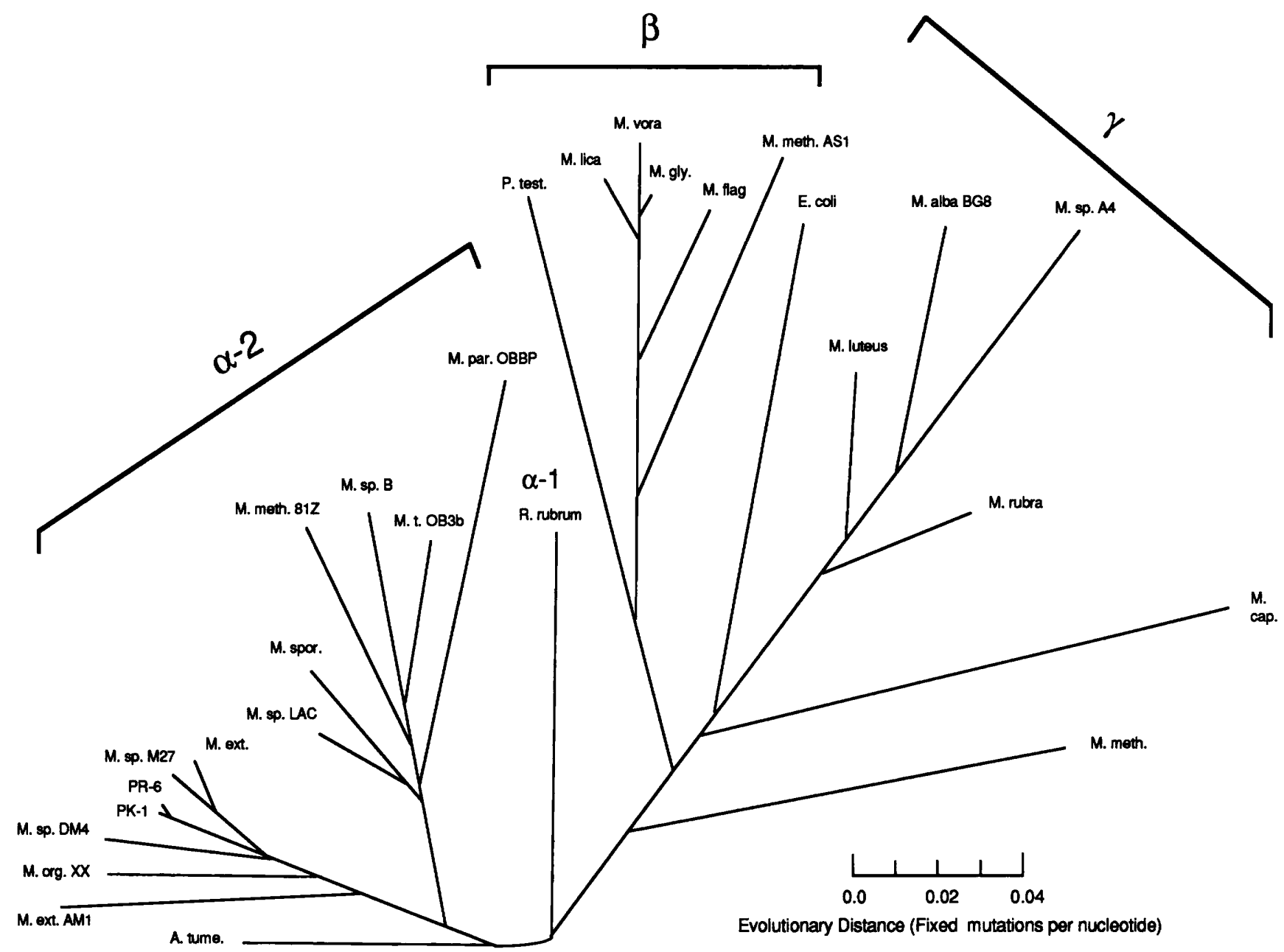

FIG. 1. Unrooted phylogenetic relationship among methylotrophic bacteria and other representatives within the class Proteobacteria. The abbreviations on the tree represent the following organisms: $\alpha$-subclass reference organisms Agrobacterium tumefaciens (A. tume.) and Rhodospirillum rubrum (R. rubrum); $\alpha$-subclass methylotrophs Methylobacterium sp. strain DM4 (M. sp. DM4), Methylobacterium sp. strain M27 (M. sp. M27), Methylobacterium extorquens (M. ext.), Methylobacterium extorquens AM1 (M. ext. AM1), Methylobacterium organophilum XX (M. org. XX), strain PK-1 (PK-1), and strain PR-6 (PR-6); $\alpha$-subclass methanotrophs Methylocystis parvus OBBP (M. par. OBBP), "Methylosinus" sp. strain B (M. sp. B), "Methylosinus" sp. strain LAC (M. sp. LAC), "Methylosinus methanica" $81 \mathrm{Z}$ (M. meth. $81 \mathrm{Z}$ ), "Methylosinus sporium" (M. spor.), and "Methylosinus trichosporium" OB3b (M. t. OB3b); $\beta$-subclass reference organism Pseudomonas testosteroni (P. test.); $\beta$-subclass methylotrophs “Methylobacillus flagellatus" KT1 (M. flag.), Methylobacillus glycogenes (M. gly.), "Methylomonas methanolica" (M. lica), "Methylomonas methylovora" (M. vora), and Methylophilus methylotrophus AS1 (M. meth. AS1); $\gamma$-subclass reference organism Escherichia coli; $\gamma$-subclass methanotrophs Methylococcus capsulatus (M. cap.), Methylomonas sp. strain A4 (M. sp. A4), Methylomonas alba BG8 (M. alba BG8), Methylomonas lutea (formerly Methylococcus luteus) (M. luteus), Methylomonas methanica (M. meth.), and Methylomonas rubra (M. rubra).

portant applications, development of a useful taxonomic system is essential.

Tsuji et al. have demonstrated that it is possible to distinguish among and classify methylotrophic bacteria by using 16S rRNA sequence analysis (20). Furthermore, oligonucleotide signature probes based on the sequences were defined and applied to identify physiological groups of methylotrophic bacteria (17). The present work extends the sequence data base by considering methylotrophs and methanotrophs which utilize different pathways for formaldehyde assimilation.

Table 1 describes the salient properties of 15 new methylotrophs from which 16S rRNAs were sequenced. Isolation and reverse transcriptase sequencing of 16S rRNA from the organisms, data analysis, and phylogenetic tree construction were performed as previously described (20).
The sequences were determined with minimal ambiguities to over $90 \%$ of completion for each organism. Table 2 shows the percent homology determined for each pairing. Nine previously reported methylotroph $16 \mathrm{~S}$ rRNA sequences (20) were included in the calculations. All the values were used to develop a phylogenetic tree (Fig. 1). The tree also includes representative organisms from subdivisions within the class Proteobacteria (13, 23): Agrobacterium tumefaciens, $\alpha-2$; Escherichia coli, $\gamma ;$ Pseudomonas testosteroni, $\beta$; and Rhodospirillum rubrum, $\alpha-1$.

The serine pathway methanotrophs and methylotrophs form tight, separate clusters within the $\alpha-2$ subdivision. The genus "Methylosinus" forms a coherent group. The relationship between these organisms correlates with the observation that the members of this group produce soluble MMO, the enzyme responsible for trichloroethylene degradation ( 3 , 
19). Furthermore, the placement of strains PK-1 and PR-6, two pink-pigmented, methanol-utilizing methylotrophs isolated from garden bean plant leaves (9), with the pinkpigmented serine pathway methylotrophs of the genus $\mathrm{Me}$ thylobacterium shows the utility of this analysis in rapidly classifying methylotrophs.

The RuMP pathway methylotrophs also separated into clusters. Four methanotrophs from the Methylomonas species group together but with less cohesiveness than the serine pathway methanotrophs. The RuMP methylotrophs unable to grow on methane were found in a different cluster with Methylophilus methylotrophus AS1. The four new RuMP pathway methylotrophs sequenced for this study belong to the genera Methylomonas and Methylobacillus. The homologies, however, do not match the genus designations. Methylobacillus glycogenes is more closely related to "Methylomonas methylovora" and "Methylomonas methanolica" than to "Methylobacillus flagellatus."

The information presented in this paper expands the data base of $16 \mathrm{~S}$ rRNA sequences for methylotrophs. Moreover, the results support classical taxonomic groupings based on phenotype (22) and provide a useful and rapid tool for evaluating phylogenetic distribution of new isolates.

Nucleotide sequence accession numbers. The new nucleotide sequence data reported in this paper have been submitted to the EMBL, GenBank, and DDBJ nucleotide sequence data bases and assigned the following accession numbers: "Methylobacillus flagellatus"' KT1, M95651; Methylobacillus glycogenes, M95652; Methylobacterium sp. strain M27, M95653; Methylobacterium sp. strain PK-1, M95654; Methylobacterium sp. strain PR-6, M95655; Methylobacterium extorquens, M95656; Methylococcus luteus, M95657; Methylomonas sp. strain A4, M95658; "Methylomonas alba" BG8, M95659; "Methylomonas methanolica," M95660; "Methylomonas methylovora," M95661; "Methylomonas rubra," M95662; "Methylosinus" sp. strain B, M95663; "Methylosinus" sp. strain LAC, M95664; and "Methylosinus sporium," M95665.

This research was supported by grants to R.S.H. from the National Science Foundation (BSR 8903833) and by the United States Department of Energy through the University of Tennessee and Oak Ridge National Laboratories (UTN ORA 3546.01/SUB DOE).

The technical assistance of Sheila M. Lutz was greatly appreciated.

\section{REFERENCES}

1. Alvarez-Cohen, L., P. L. McCarty, E. Boulygina, R. S. Hanson, G. A. Brusseau, and H. C. Tsien. 1992. Characterization of a methane-utilizing bacterium from a bacterial consortium that rapidly degrades trichloroethylene and chloroform. Appl. Environ. Microbiol. 58:1886-1893.

2. Anthony, C. 1982. The biochemistry of methylotrophs. Academic Press, Inc., London.

3. Brusseau, G. A., H. C. Tsien, R. S. Hanson, and L. P. Wackett. 1990. Optimization of trichloroethylene oxidation by methanotrophs and the use of a colorimetric assay to detect soluble methane monooxygenase activity. Biodegradation 1:19-29.

4. Burrows, K. J., A. Cornish, D. Scott, and I. J. Higgins. 1984. Substrate specificities of the soluble and particulate methane monooxygenases of Methylosinus trichosporium OB3b. J. Gen. Microbiol. 103:3327-3333.

5. Galchenko, V. F., L. V. Andreen, and Y. A. Trotsenko. 1986. Taxonomy and identification of obligate methanotrophic bacteria. Academic Press, USSR Academy of Science, Puschino, Russia.

6. Govorukhina, N. I., L. V. Kletsova, Y. D. Tsygankov, Y. A.
Trotsenko, and A. I. Netrusov. 1987. Characteristics of a new obligate methylotroph. Mikrobiologiya 56:673-677. (In Russian.)

7. Hanson, R. S., A. I. Netrusov, and K. Tsuji. 1991. The obligate methanotrophic bacteria Methylococcus, Methylomonas, and Methylosinus, p. 2350-2364. In A. Balows, H. G. Trüper, M. Dworkin, W. Harder, and K. H. Schliefer (ed.), The procaryotes, vol. 3. Springer-Verlag, New York.

8. Higgins, I. J., D. J. Best, R. C. Hammond, and D. Scott. 1981. Methane-oxidizing microorganisms. Microbiol. Rev. 45:556590.

9. Hirano, S. (University of Wisconsin). 1992. Personal communication.

10. Oldenhuis, R., R. L. J. M. Vink, D. B. Janssen, and B. Witholt. 1989. Degradation of chlorinated aliphatic hydrocarbons by Methylosinus trichosporium OB3b expressing soluble methane monooxygenase. Appl. Environ. Microbiol. 55:2819-2826.

11. Romanovskaya, V. A., Y. R. Malashenko, and Z. N. Bogachenko. 1978. Corrected diagnosis of the genera and species of methane-utilizing bacteria. Mikrobiologiya 47:120-129. (In Russian.)

12. Scholtz, R., L. P. Wackett, C. Egli, A. M. Cook, and T. Leisinger. 1988. Dichloromethane dehalogenase with improved catalytic activity isolated from a fast-growing dichloromethaneutilizing bacterium. J. Bacteriol. 170:5698-5704.

13. Stackebrandt, E., R. G. E. Murray, and H. G. Trüper. 1988. Proteobacteria classis nov., a name for the phylogenetic taxon that includes the "purple bacteria and their relatives." Int. J. Syst. Bacteriol. 38:321-325.

14. Stirling, D. I., J. Colby, and H. Dalton. 1979. A comparison of the substrate and electron-donor specificities of the methane monooxygenases from three strains of methane-oxidizing bacteria. Biochem. J. 177:361-364.

15. Strand, S. E., and M. E. Lidstrom. 1984. Characterization of a new marine methylotroph. FEMS Microbiol. Lett. 21:247-251.

16. Topp, E., and R. S. Hanson. 1991. Metabolism of radiatively important trace gases by methane-oxidizing bacteria, p. 71-90. In J. E. Rogers and W. B. Whitman (ed.), Microbial production and consumption of greenhouse gases: methane, nitrogen oxides, and halomethanes. American Society for Microbiology, Washington, D.C.

17. Tsien, H. C., B. J. Bratina, K. Tsuji, and R. S. Hanson. 1990. Use of oligonucleotide signature probes for identification of physiological groups of methylotrophic bacteria. Appl. Environ. Microbiol. 56:2858-2865.

18. Tsien, H. C., G. A. Brusseau, R. S. Hanson, and L. P. Wackett. 1989. Biodegradation of trichloroethylene by Methylosinus trichosporium OB3b. Appl. Environ. Microbiol. 55:3155-3161.

19. Tsien, H. C., and R. S. Hanson. 1992. Soluble methane monooxygenase component $B$ gene probe for identification of methanotrophs that rapidly degrade trichloroethylene. Appl. Environ. Microbiol. 58:953-960.

20. Tsuji, K., H. C. Tsien, R. S. Hanson, S. R. DePalma, R. Scholtz, and S. LaRoche. 1990. 16S ribosomal RNA sequence analysis for determination of phylogenetic relationship among methylotrophs. J. Gen. Microbiol. 136:1-10.

21. Whittenbury, R., and H. Dalton. 1983. The obligate methaneoxidizing bacteria and their biotechnological potential, p. 439 460. In A. Hollaender, A. I. Laskin, and P. Rogers (ed.), Basic biology of new developments in biotechnology. Plenum Press, New York.

22. Whittenbury, R., and N. R. Krieg. 1984. Methylococcaceae fam. nov., p. 256-261. In N. R. Krieg and J. G. Holt (ed.), Bergey's manual of determinative bacteriology, vol. 1. The Williams \& Wilkins Co., Baltimore.

23. Woese, C. R. 1987. Bacterial evolution. Microbiol. Rev. 51:221271.

24. Yordy, J. R., and T. L. Weaver. 1977. Methylobacillus: a new genus of obligately methylotrophic bacteria. Int. J. Syst. Bacteriol. 27:247-255.

25. Zatman, L. 1981. A search for patterns in methylotrophic pathways, p. 42-54. In H. Dalton (ed.), Microbial growth on $\mathrm{C}_{1}$ compounds. Heyden, London. 